\title{
DACE BALODE
}

\section{ĢIRTS ROZNERS}

\section{FUNDAMENTĀLISMS KĀ KRISTĪGĀS TICĪBAS FENOMENS LATVIJĀ}

Lai arī fundamentālisma jēdziens ir radies 19. un 20. gadsimta mijā un tika attiecināts uz noteiktu protestantiskās ticības virzienu, mūsdienās tas tiek izmantots arvien plašāk, raksturojot visdažādāko reliğisko pārliecību un ticību prakses. Šodien daudz varam dzirdēt, piemēram, par islāma fundamentālismu. Arī karojošs ateisms tiek raksturots kā kristīgā fundamentālisma spogul̦attēls, jo izmanto tās pašas kristīgā fundamentālisma paradigmas, tikai ar pretējiem nolūkiem. ${ }^{1}$ Mūsu mērk̦is ir aplūkot fundamentālismu tā sākotnējā kontekstā kā protestantiskās ticības fenomenu un meklēt atbildes uz trim jautājumiem:

1. Kā šodien definēt protestantisko fundamentālismu?

2. Ar ko raksturīga protestantiskā fundamentālisma hermeneitika un eksegèēze?

3. Vai varam runāt par fundamentālismu Latvijas kontekstā?

1 Skatīt Liam Jerrold Fraser, Atheism, Fundamentalism and the Protestant Reformation (Cambridge, University Press, 2018). 


\section{Bībeles verbālā inspirācija kā fundamentālisma izejas punkts}

Šveices teologs Ulrihs Lucs (Luz) lekcijās par Jaunās Derības hermeneitiku raksturoja protestantu fundamentālismu kā sava veida ortodoksā protestantisma fosiliju. ${ }^{2}$ Lai arī doma par inspirētiem Svētajiem Rakstiem (tostarp autora, teksta, satura un pat katra atsevišķā vārda inspirāciju) kristīgajā teoloǵijā pastāvēja jau agrāk, tomēr tikai pēc Reformācijas verbālās inspirācijas doktrīna kļuva par ortodoksā protestantisma teologijas stūrakmeni. Raksti tika ielikti teologiijas centrā. Lai aizstāvētu protestantisko teoloǵiju kā līdzvērtīgu iepretī katoliskās baznīcas tradīijai, bija nepieciešams atrisināt jaunas autoritātes jautājumu. Pretstatā baznīcai, kas pildīja teologiijas tradīiijas un avota funkciju, bija nepieciešams objektivizēt un absolutizēt Rakstus kā teoloǵijas avotu, piešķirot tiem ārkārtīgi augstu autoritāti.

Gan Rietumu patristiskā tradīcija, gan sākotnējais ortodoksais protestantisms uzsvēra Rakstu autoru inspirāciju, kas pię̧āva, ka autori Svētajos Rakstos ietvertās domas formulēja paši ar saviem vārdiem. Tomēr jau Matiasa Flācija (1520-1575) hermeneitikā par faktisko teksta autoru tika nosaukts Dievs: "Visu svēto grāmatu autors ir viens, nevis vairāki un atšksirīgi, proti, pats Dievs ... kaut arī Dievs laiku pa laikam dažādos veidos ir runājis uz cilvēci caur dažādiem cilvēkiem, tomēr visi šie vārdi un pasludinājumi ir lieliskā saskañā cits ar citu." ${ }^{3}$ Cits luterāņu teologs - Johans Gerhards (Gerhard, 15821637) - rakstija, ka Bībeles grāmatu autori bija "Dieva rakstveži" (Dei amannuenses), īpašas personas, kuras izvēlējās kalpot par Svētā Gara instrumentiem. Inspirācijas procesā autoru paša griba tika izslēgta, un viņi pierakstija tikai tos vārdus, kurus viņiem deva Dievs. ${ }^{4}$ Daži luterāñu teologi pat gāja tik tālu, ka par inspirētiem uzskatỉja ebreju

2 Ulrihs Lucs, Jaunās Derības hermeneitika, Lekcija Bernes Universitātē, ZS 2002/2003. Nepublicēts materiāls.

3 Matthias Flacius Illyricus, Clavis Scripturae Sacrae 1567 (Frankfurt, 1719) Bd. II, 62; citēts pēc Emmanuel Hirsch, Hilfsbuch zum Studium der Dogmatik, 3. Aufl. (Berlin, 1958), 314.

4 Piemēram, 2. gadsimta baznīctēvs Irenejs apraksta brīnumaino procesu, kā ebreju Bībele tika tulkota grieķu valodā. Viņš raksta par 70 tulkotājiem, kas katrs atsevišķi iztulkoja visu Toru grieķu valodā, un, kad šos tulkojumus salīdzināja, tie visi bija vienādi. Tā pat pagāniem bija jāatzīst, ka "Svētie Raksti ir tulkoti ar dievišksu iedvesmu". Iraeneus, Adv. Haer. III, 21, 2. Contre les hérésies. Irénée de Lyon, éd. critique par Adelin Rousseau et Louis Doutreleau (Paris: Ed. du Cerf, 1974), 404.Ekl. Inspiration, RGG3, Bd. lii, 776-778.

"Attīstot Svēto Rakstu doktrīnu kā teoloǵijas "principu", ortodoksais luterisms (Johans Gerhards) pārspēja reformatorus, piedēvējot Bībelei visas īpašības, kuras, saskaņā ar Aristoteli, pieder pie pirmā zinātniskā principa. Pirmais princips ir nedalāms, patiess un brīvs no jebkādas kritikas, pats sevi apstiprina, nav pretrunīgs un neprasa pierādijumus." Johannes Wallmann, Pietismus und Orthodoxie (Tübingen: Mohr Siebeck, 2010), 293. Hirsch, Hilfsbuch zum Studium der Dogmatik, 314, Johann Gerhard bei Heinrich Schmid, Die Dogmatik der evangelisch-lutherischen Kirche (Erlangen, 1843), 21. Schmid, Die Dogmatik der evangelisch-lutherischen Kirche, 18. 
tekstam vēlāk pievienotās vokalizācijas zīmes un arī Rakstu senos tulkojumus. Tādā veidā viss Bībeles teksts un pat katrs Bībeles vārds tika padarìts par vienlīdz svarīgiem, līdz ar to nebija vairs legitīima galvenā vēstijjuma meklēšana, pēc kā vērtēt un izsvērt pārējo tekstu, vairs nebija iespējama "kanona kanonā" meklēšana. ${ }^{5}$

Šĩ doma piešķīra Bībeles tekstam milzīgu autoritāti. Kad katrs tās vārds ir Dieva nodiktēts, vienīgā atbilde no cilvēka var būt tikai ticība un paklausība. Teksts iepretī lasītājam kḷuva par ārkārtīgi autoritatīvu sarunu biedru. Rakstu patiesums un uzticamība balstijāàs to pārdabiskajā izcelsmē. Tie bija jāsaprot vienīgi kā Dieva vārds un vienīgais avots zināšanām par Dievu. Lai tas varētu pildīt šo funkciju, tam ir jābūt nevainojamam, skaidram un spēcīgam. ${ }^{6}$

Ja šãda doktrīna par nekḷūdīgiem un skaidri saprotamiem Svētajiem Rakstiem ir patiesa, tad tai vajadzētu rezultēties skaidrā un nepretrunīgā interpretācijā, jo Dievs nevar būt pretrunā ar sevi ne Rakstos, ne interpretācijā, kas saka tikai to, "kas ir Svētajos Rakstos". Ir jābūt tikai vienai patiesībai. Tomēr turpmākajos gadsimtos viss notika pavisam citādi. Vienotas un skaidras izpratnes vietā radās arvien vairāk kristīgās tịcības virzienu atšķiirīgās interpretācijas, kuras visas apgalvoja, ka ir patiesas. Vienveidību arvien vairāk nomainīja plurālisms, un, kā uzskata teologs Ulrihs Lucs, tieši ar to brīdi sākās hermeneitiskā polemika par teksta patieso nozīmi, kas arvien vairāk un vairāk lika atzīt lasītāja lomu, ka katru interpretāciju ietekmē paša teksta lasītāja konteksts un ka lasīt nozīmē konstruēt nozīmi. ${ }^{7}$ Arī vēsturiski kritiskās eksegēēzes zinātniskie centieni objektīvi interpretēt tekstu noveda pie bezgalīgu hipotēžu pasaules.

Turpmākie gadsimti parādīja, ka, pat ja tāds absolūts (tikai patiess) teksts pastāvētu, mēs tik un tā nevarētu to saprast vienādi, jo neizbēgami mēs tekstu lasām caur mūsu biogrāfijas un kultūras konteksta brillēm un tāpēc katrs tajā saskatām atšḳirīgu

5 Flācijs brīdina, ka Baznīca nedrīkst piel̦aut "velna doktrīnu", ka ebreju tekstā ierakstītie patskañi ir rakstīti vēlāk. Citādi viss teksts vairs nebūs uzticams. Hirsch, Hilfsbuch zum Studium der Dogmatik, 778.

6 Ortodoksā protestantisma dogmatikā tiek uzskaitītas vismaz četras pazīmes, kas raksturo Svētos Rakstus: 1. auctoritas; 2. sufficientia; 3. claritas un 4. efficacia. Pirmkārt, Rakstu ekskluzīvā autoritāte ir izteikta kā Dieva vārds. Otrkārt, Raksti satur visu, kas jāzina pestǐšanai; nav nepieciešams cits atklāsmes avots. Treškārt, viss, kas nepieciešams pestī̌sanai, ir skaidri izteikts Rakstos, ko var saprast arī neizglìtoti ticīgie. Ceturtkārt, Raksti ir iedarbīgs Vārds, kas spēj cilvēkos pamodināt ticību. Schmid, Dogmatik, 27.30, Ulrich Luz, Theologische Hermeneutik des Neuen Testaments (Neukirchen-Vluyn, 2014), 109. Arī piētisti stingri turējās pie idejas par verbāli inspirētu tekstu. Piemēram, piētists Filips Jakobs Špēners (1603-1666) pārņēma verbālās inspirācijas ideju no sava skolotāja Johana Konrāda Danhauera (1635-1705) un turējās pie tās visu mūžu. Viñš uzskatīja, ka doma, ka Bībelē varētu būt kḷūdas, ir bīstama. Špēners domāja, ka inspirēti ir ne tikai autori, bet arī Svēto Rakstu vārdi. Wallmann, Pietismus und Orthodoxie, 293-294.

7 Luz, Theologische Hermeneutik.., 112-113. 
patiesību. Neskatoties uz to, līdz pat mūsu dienām kristīgajā teoloğijā ir aprindas, kas turpina runāt par verbālu Bībeles inspirāciju un no tā izrietošu Rakstu nekḹūdīgumu un nemaldīgumu. Aizvadītā gadsimta vidū, saasinoties kontraversei starp modernismu un fundamentālismu, Ziemel̦amerikā norisinājās šķelšanās gan luterāņu, gan prezbiterāņu, gan baptistu konfesijā. Tā ietekmē Bībeles nekḷūdīguma aizstāvji 1978. gadā čikāgā organizēja samitu, kurā piedalijās aptuveni 300 evangééliskie teologi galvenokārt no ASV un izstrādāja dokumentu, kas ir pazīstams kā "Čikāgas Bībeles nekḷ̂ūīguma deklarācija" (Chicago Statement of Biblical Inerrancy). Viens no tās punktiem ir: "Mēs atzīstam, ka Raksti kopumā un katra tā atsevišķā dal̦a līdz pat oriǵinālteksta vārdiem ir doti ar dievišksas inspirācijas palīdzību." ${ }^{8}$

Tas atgādina 17. gadsimta ortodoksā protestantisma uzskatus par Bībeles inspirāciju. Acīmredzot ortodoksajam protestantismam raksturīgais augstais skatījums uz Bībeli turpināja savu eksistenci (vai Ulriha Luca vārdiem runājot, ir fosilizējies) mūsdienu evanģelikālismā, ko bieži vien apzīmē kā fundamentālismu tam raksturīgās Bībeles interpretācijas dēḷ.

\section{Kas ir fundamentālisms?}

Vārda "fundamentālisms" izcelsme ir meklējama protestantisma vēsturē Amerikā 19. gadsimta beigās. Tā bija pretošanās kustība pret arvien pieaugošo teolog̣isko liberālismu un moderno zinātni, kurā dominēja evolūcijas ideja. Laikā no 1910. līdz 1915. gadam tika izveidota 12 sējumu sērija "The Fundamentals: A Testimony to the Truth", kurā galvenais uzsvars tika likts uz Bībeles nemaldīgumu un nekḷūīigumu un burtisku tās interpretāciju attiecībā uz tajā aprakstītajiem notikumiem, piemēram, pasaules radīšanu sešās dienās un nevis evolūcijas cel̦ā. Šis izdevums deva nozīmīgu impulsu fundamentālisma sākumam un tālākai pastāvēšanai. ${ }^{9}$

Tomēr fundamentālisma kustības saknes meklējamas daudz dzil̦āk - 19. gadsimta ekonomiskajā un politiskajā nenoteiktībā. Šajā laikmetā Amerikā notika būtiskas sociālās un ekonomiskās pārmainas - industrializācija, strauja pilsētu izaugsme un visbeidzot plaša, viḷnveidīga imigrācija. Pirmā globālā ekonomiskā krīze (1857) un pilsoņu karš 1861.-1865. gadā parādijja, cik nestabila ir politiskā un ekonomiskā situācija. Mainījās arī zinātne. Čārlza Darvina izstrādātā evolūcijas teorija kḷuva par zinātniski pamatotu teoriju, bet citi uzskati tika noraidīti kā pasakas. Bībeles pētniecībā tas bija "augstās kritikas" laiks, tika atklāta Bībeles tekstu izcelsmes vēsture, to ietekmēšanās

8 "We affirm that the whole of Scripture and all its parts, down to the very words of the original, were given by divine inspiration." https://defendinginerrancy.com/chicago-statements/ (skatīts 26.08.2020.)

9 Art. "Fundamentalismus", $R G G^{3} \mathrm{Bd}$. II, $1178 \mathrm{f}$. 
un atkarība no vēsturiskā konteksta. Šĩ situācija bija pateicīgs pamats radikālās atmodas pasludinājumam, kas norādīja uz vispārējo dekadenci, vēstija par nenovēršamu pēdējo cīṇu starp labo un l̦auno, mudināja turēties pie Bībeles patiesības. ${ }^{10}$ Tā ietekmē kristieši, īpaši no baptistu, prezbiteriāñu, kā arī metodistu un luterāņu aprindām, nošķ̄īrās no pārējām draudzēm un apvienojās konferencēs. ${ }^{11}$ Prinstonas teologiskā semināra teologi, kuri sevi uzskatijja par ortodoksā protestantisma pēctečiem, 1881. gadā formulēja verbālās inspirācijas doktrīnu. Pamatojoties uz šo doktrīnu, Prezbiterāṇu baznīcas augstākā autoritāte Ģenerālā asambleja formulēja piecus "pamatus" (fundamentals), kas fundamentālistu aprindās ir joprojām atzīti arī mūsdienās: 1) Bībele kā verbāli inspirēta Dieva atklāsme; 2) Kristus augšāmcelšanās miesā; 3) piedzimšana no jaunavas; 4) Kristus vietnieciskais upuris; 5) viņa fiziska atgriešanās. ${ }^{12}$

Ne visi šie punkti bija vienlīdz svarīgi, galvenais bija nodrošināt Bībeles autoritāti, izvairīties no Jēzus Kristus reducēšanas tikai līdz cilvēciskam līmenim, cilvēka izcelsmes ar dievišķas radošas darbības palīdzību apšaubǐšanas un dvēseles glābšana tuvojošās Jēzus otrās nākšanas laikā. ${ }^{13}$ Saskaroties ar mainīgo pasauli, fundamentālisms centās palikt nemainīgs. Tāpēc kristīgais fundamentālisms varētu tikt uzskatīts par antimodernismu, kas ideologiski vēlas atgriezties pirmsapgaismības laikmetā. Tomēr šāds apgalvojums būtu l̦oti iešaurināts. Kā norāda pētnieki, fundamentālisms nav kāds autonoms pats par sevi pastāvošs antimodernisms, bet gan jāaplūko kā modernās pasaules sastāvdaļa, kurā notiek pastāvīga kontraverse starp modernismu un fundamentālismu. Fundamentālisti nebēg no modernā, bet meklē tajā savu vietu un lomu. Tāpēc mūsdienu fundamentālisti ir gan politiski, gan ekonomiski aktīvi. No vienas puses, viņi pieņem nacionālās valsts un brīvā tirgus sistēmu, bet, no otras puses, ja vien tas būtu iespējams, dotu priekšroku citām sistēmām, kas būtu konstruētas uz reliǵiskiem principiem. Fundamentālisti labprāt izmanto modernās tehnolog̣ijas, tomēr arī kritizē, kad tās tiek lietotas amorālos nolūkos. Epistemiologiiski viṇi ir pārliecināti pamatisti, jo uzskata, ka

10 Piemēram, anglu sludinātājs Džons Nelsens Darbijs (1800-1882), kurš sešas reizes devās uz ASV laikā no 1859. līdz 1877. gadam un ieguva arvien vairāk un vairāk sekotāju savai mācībai. S. Goertz, et al., „Zur Genealogie und Kritik des katholischen Fundamentalismus: Eine Einführung“ in: Stephan, Goertz/Rudolf B., Hein/Katharina, Klöcker (Hg.), Fluchtpunkt Fundamentalismus? Gegenwartsdiagnosen katholischer Moral (Freiburg i. Br., 2013), 15-17.

11 Niagāras Bībeles konferencē 1868. gadā prezbiteriānis Džeimss Brūkss (James H. Brookes, 1830-1897) noformulēja savus uzskatus - ticības fundamentus. Goertz, Genealogie, 19.

12 Assia Maria Harwazinski, "Fundamentalism" in: The Brill Dictionary of Religion, ed. by Kocku von Stuckrad. http://dx.doi.org/10.1163/1872-5287_bdr_COM_00176 (skatīts 20.04.2020.)

13 Klaus Kienzler, Der religiöse Fundamentalismus: Christentum, Judentum, Islam (München, 1996), 30. 
jebkurām zināšanām un ticībai ir jābalstās uz stipriem racionāli empīriskiem pamatiem. Piemēram, ka Bībeles uzticamība ir zinātniski pierādīts fakts. ${ }^{14}$

Politologs Tomass Meiers (Meyer) fundamentālismu uzskata par Apgaismības un modernizācijas radītās dialektikas rezultātu. Modernizācija ne tikai "aizslaucīja aizspriedumus, šķēršlus un visu tradīcijas būtību, bet tikpat pamatīgi pārliecības, mierinošās fikcijas, nišas, kuru veidošanos iepriekšējās tūkstošgadēs noteica spēcīgas vajadzības”" Tas nozīmē, ka fundamentālisms ir ar krīzi saistīta kustība, lai izvairītos no pārmērīgās sekulārās modernitātes piesārņojuma un meklētu stabilu pamatu un drošu virzienu. Pēc Meiera teiktā, šĩ kustība var notikt dažādu iemeslu dẹl, taču tā ir tikpat universāla kā pati modernitāte un nekādā gadījumā nav uzskatāma vienīgi par Rietumu fenomenu. Fundamentālisms kā pretošanās modernitātei ir vērojams visur, kur notiek pārmaiņas, kas atver kultūras, sociālās un politiskās sistēmas. ${ }^{16}$

Fundamentālisms nav vērsts pret visu modernitāti kā tādu, tikai pret noteiktiem aspektiem, kas tiek uztverti kā atteikšanās no jēgas, morāles vai reliǵijas. Tas tomēr nav uzskatāms par atgriešanos pirmsapgaismības laikmetā, jo fundamentālismu izraisa dialektika starp mūsdienu parādībām un pretreakciju tām. ${ }^{17}$ Tajā pašā laikā fundamentālisms pieñem modernas idejas, viegli pielāgojas tehnoloǵiju un racionalizācijas progresam. Tas ir "modernais antimodernisms", kā to saka reliǵijas pētnieks Gotfrīds Kinclens (Küenzlen). ${ }^{18}$ Tā nav vienkārša atgriešanās pagātnē, tā nav fosilija, tas nav nekas novecojis, kam šodien vairs nevar ticēt vai domāt. Gluži pretēji, tā ir mūsdienu parādība. Tas ir mūsdienu cilvēka prāta stāvoklis un vajadzība.

20. gadsimta 70. un 80. gados termins "fundamentālisms" tika pārnests uz kustībām ne tikai kristietībā, bet arī jūdaismā, islāmā un hinduismā, kā arī politiskajās un

14 Harriet A. Harris, "Foundamentalism in Protestant Context" in Foundamentalism, Church and Society, ed. by Martyn Percy and Ian Jones (London: Society for Promoting Christian Knowledge, 2002), 12.

15 Thomas Meyer, "Fundamentalismus. Die andere Dialektik der Aufklärung" in: Der Fundamentalismus: Aufstand gegen die Moderne (Reinbek bei Hamburg: Rowohlt Taschenbuch Verlag, 1989), 15.

16 Thomas Meyer, Fundamentalismus. Die andere Dialektik der Aufklärung, 17. Thomas Meyer, Was ist Fundamentalismus?: eine Einführung (Wiesbaden: VS Verlag für Sozialwissenschaften, 2011), 21-23.

17 Martin Riesebrodt, Die Rückkehr der Religionen: Fundamentalismus und der „Kampf der Kulturen” (München, 2000), 50-52.

18 Saskaņā ar Kīnclenu, fundamentālisms ir reliǵijas vēstures izpausme mūsdienu laikmetā. Fundamentālisms kā "modernais antimodernisms" ir karojoša pretošanās modernitātes izraisītajām religijijas pārmaiņām, kas, viņaprāt, apdraud patiesību ar relatīvismu, plurālismu, historismu un autoritātes zaudēšanu. Gottfried Küenzlen et al., „Fundamentalismus”, in: Religion in Geschichte und Gegenwart. http://dx.doi.org/ (skatīts 10.04.2020.) 
sociālajās kustībās. ${ }^{19}$ Terminu vairs neizmantoja vienā noteiktā nozīmē, bet gan sāka attiecināt uz dažādām mentalitātēm. Fundamentālisms vairs nebija noteiktu reliǵiju vai pasaules uzskatu raksturojošs apzīmējums, bet drīzāk termins, ar ko reaǵèt uz noteiktām sociālpsihologiiskām norisēm. Lĩdz ar to šis termins var tikt attiecināts arī uz nereliǵiozām parādībām un kopumā apzīmē jebkuru filozofisku un reliǵisku attieksmi, kas apgalvo, ka tai ir absolūta patiesība, kuru principā nevar apšaubīit. ${ }^{20}$

Tāpēc bieži vien ir grūti nošķirt fundamentālismu no citām konservatīvām kristiešu kustībām. Grūtības rada tas, ka terminu bieži izmanto, lai runātu par trešo personu nievājošā nozīmē, apzīmējot liberālu un atšķirīgu mentalitāti. Tas liek jautāt, cik lielā mērā fundamentālisms kā kategorija joprojām var būt noderīgs. Šķiet, ka vēl grūtāk ir nošḳirt terminus "evaņgélikālis" un "fundamentālists", jo îpaši tāpēc, ka tos bieži izmanto kā sinonīmus. Grūtības slēpjas arī tajā, ka abi termini apzīmē vēsturiski un teolog̣iski atšķirīgas parādības. Baznīcas vēsturnieces Gizas Baueres (Bauer) gandrīz 25 lappušu garais pētijums par evanggelikālismu un fundamentālismu liecina, ka savā ziņā skaidra atšķirība starp tiem nav nosakāma: "Ja pieñem, ka kristīgo fundamentālismu var aplūkot no historiogrāfiskā viedokḷa kā evaņǵelikālismam raksturīgu tendenci vai kategoriju, kas savukārt ir veidojusi evanggelikālismu, tēze par būtisku atšķirību starp abām parādībām kḷūst neaizstāvama." ${ }^{21}$

Faktiski atšķirību diez vai var pamatot ar teoloǵiskām atšķirībām, jo, piemēram, Bībeles nekḷūdīgums un uzsvars uz personisku dievbij̄̄īu ir svarīgi abiem. To pašu var teikt par mūsdienu Bībeles zinātnes un vēsturiski kritiskās metodes noraidīšanu. Atšķirību starp evangégelikālismu un fundamentālismu var novērot no politiskās aktivitātes viedokḷa - fundamentālisms ir politiski aktīva kustība, turpretim evanggelikālisms ir baznīcai kritiska, drīzāk piētiska kustība, kas vērsta uz sirds iekšēju dievbij̄̄bu. Abi ir saistīti ar kritisku diskusiju ar "pasauli", tāpēc abiem raksturīgi līdzīgi centieni dažādos kontekstos. ${ }^{22}$ Vēl atšķirību varētu saskatīt ārējā attieksmē - fundamentālists varētu būt "evanggelikālis, kurš ir dusmīgs"23. Tad atšķirība būtu tāda, ka evangéelikālisms vienmēr ir atvērts dialogam ar ārpasauli, turpretī fundamentālisms uzstāj uz arvien ekskluzīvāku izpratni par sevi un patiesību un ir slēgta vai pat agresīva kustība protestantismā, kas

19 Goertz, Genealogie, 25-27.

20 Christian J. Jäggi, David J. Krieger, Fundamentalismus. Ein Phänomen der Gegenwart (Zürich, Wiesbaden: Orell Füssli, 1991), 16.

21 Gisa Bauer, Evangelikale Bewegung und evangelische Kirche in der Bundesrepublik Deutschland: Geschichte eines Grundsatzkonflikts (1945 bis 1989) (Göttingen, 2012), 97-98.

22 Bauer, Bewegung, 104. Viña atgādina, ka fundamentālistu kustības dzīvo ilgāk nekā to politiskās iniciatīvas pat tad, ja tās ir neveiksmīgas, tāpēc tās nekādā gadījumā nevajadzētu saprast kā politizētu reliğiju. Turpat, 105.

23 George M. Marsden, Fundamentalism and American Culture (Oxford, 2006), 239. 
uzstāj uz mūžīgo patiesību, nemainīgu morāli un tic Bībeles nekḷūī̄gumam. Andreass Grīnšloss (Andreas Grünschloß) savā pētījumā līdzās jau minētajai ticībai Bībeles absolūtajam nemaldīgumam un nekḷūdīgumam min arī fundamentālismam raksturīgo izteikti morāli duālistisko pasaules uzskatu, mileniārismu un reaktivitāti (fundamentālisms ir reakcija uz religijas marginalizāciju). Šìs pazīmes viņš ierindo pie fundamentālisma ideolog̣iju raksturojošām pazīmēm, bet papildus šīm piemin arī fundamentālisma organizatoriskās pazīmes, kas ietver pašizpratni, ka attiecīgā kopiena ir izredzēto sabiedrība, nepieciešamība pēc asu robežlīniju vilkšanas, autoritatīva organizācijas struktūra un stingri uzvedības priekšraksti. ${ }^{24}$ Tātad fundamentālisms nav vienīgi pārliecību, ticību un uzvedību raksturojošs fenomens, bet izpaužas arī kopienas pārvaldes sistēmās, kas var būt hierarhiskas, autoritatīvas un kontrolējošas.

\section{Bībeles eksegēēze fundamentālismā}

Attiecībā uz Bībeles eksegēēzi ir ārkārtīgi grūti skaidri nodalìt dažādas tā dēvētās "Bībelei uzticīgās” interpretācijas. Manfreds Ēmings (Oeming) cenšas nošķirt konservatīvo, evaņgelikālo un fundamentālistisko eksegēēzi. Konservatīvā ir eksegēze, kas pieņem kritiskās Bībeles interpretācijas metodes, tomēr par mērksi izvirza iegūtos pētnieciskos rezultātus interpretēt tā, lai pēc iespējas aizstāvētu Bībeles vēsturiskumu. Evanggelikālā eksegēēze noraida vēsturiski kritisko pētniecības metodi kā ateistisku un turas pie Rakstu burtiskās izpratnes un teksta nekl̦ūdīguma. Fundamentālisms vēl vairāk uzsver Bībeles nemaldīgumu vissīkākajās detal̨ās. ${ }^{25}$

Kā redzams no šīs definīcijas, ir l̦oti grūti novilkt skaidru robežu starp evanggelikālo un fundamentālisma Bībeles pētniecības metodi. Patiesībā formulējumi attiecībā uz Bībeles tekstu ir l̦oti līdzīgi abiem virzieniem, jo Bībeles autoritāte galvenokārt tiek apstiprināta ar tās izcelsmes vēsturi, proti, Bībeles oriǵinālais teksts ir vārds vārdā Svētā Gara nodiktēts jeb verbāli inspirēts. Kḷūdas un nepilnības tekstā ir ieviesušās vienīgi vēlākajā pārrakstīšanas procesā. Tomēr principiāli teksts ir nemaldīgs un nekḷūīigs, un tāpēc tajā nav un nevar būt nekādas pretrunas. Līdz ar to fundamentālismā netiek saskatīta atšksirība starp realitāti, kāda tā ir, realitāti, ko piedāvā teksts, un realitāti, kas tiek iegūta interpretācijas ceḷā. Ja mēs gribētu apkopot galvenos fundamentālisma eksegèzes principus, tie būtu - Bībeles teksts ir verbāli inspirēts, tāpēc nemaldīgs, neklūūīgs un brīvs no jebkādām pretrunām. Vecā Derība ir pakārtota Jaunajai Derībai un jāsaprot tikai Jaunās Derības kontekstā. Tāpat nav vietas uzskatam, ka notiek kaut

24 Andreas Grünschloß, “Was heißt Fundamentalismus? - Zur Eingrenzung des Phänomens aus religionswissenschaftlicher Sicht" in: Tim Unger (Hg.), Fundamentalismus und Toleranz (Hannover, 2009), 163-195. http://wwwuser.gwdg.de/ agruens/fund/fund.html (skatīts 10.09.2020.)

Manfred Oeming, Biblische Hermeneutik: eine Einführung (Darmstadt, 1998), 154-155. 
kāda vēsturiska attīstība, jo Bībeles mācība bija noformulēta un gatava brīdī, kad tika uzrakstīta pēdējā Jaunās Derības kanona grāmata. Šĩ mācība laika gaitā ir nemainīga un absolūta.

Fundamentālistu eksegeēeē Bībeles interpretācijas mērķis ir noskaidrot, kas cilvēkam ir jādara. Fundamentālistiskās eksegēzes uzdevums ir teksta nozīmes tieša pārnese lasītāja kontekstā, jo Bībeles vēstijums pirmkārt attiecas uz lasītāju, piemēram, Pāvils neraksta ne romiešiem, ne korintiešiem, bet teksts ir adresēts visiem lasītājiem visos laikos. Tas ir universāls un vienlīdz derīgs kā senajiem, tā mūsdienu lasītājiem. ${ }^{26}$ Līdz ar to log̣iska arī ir fundamentālistu hermeneitikas raksturīgā pazīme, kas faktiski ir hermeneitikas noliegums. Tas pamatojas redzējumā, ka Bībele vispār nav jāskaidro, bet jāsaprot burtiski kā dzīves noteikumu un recepšu grāmata, kam vienkārši jāseko. Bībele ir skaidra un saprotama, un tajā nav nekādu pretrunu. Tie, kas tajā atrod pretrunas, ir subjektīvi un tendenciozi skaidrotāji. Jebkādi kritiskās Bībeles pētniecības atradumi un secinājumi tiek atspēkoti un noraidīti, jo to atzīšana par patiesiem sagraus visus kristīgās ticības pamatus. ${ }^{27}$

Fundamentālisti noraida vēsturiski kritisko Bībeles pētniecības metodi, jo tai ir pavisam citi mērḳi. Tāpēc vēsturiski kritiskās un fundamentālistiskās eksegeēzes rezultāti ir pavisam atšķirīgi, piemēram, ja saskaņā ar evaņgêeliju tekstiem Jēzus pabaroja lielu pūli vismaz trīs reizes, tad tas tā arī notika, un to ir svarīgi ņemt vērā, jo Bībele ir jāsaprot burtiski. Burtiskais lasījums ir drošs kristīgas tradīcijas un kristīgo vērtību apologètiskais pamats, jo tikai Bībeles patiesības ievērošana var būt vienīgā efektīvā atbilde modernā laikmeta zudušo vērtību un plurālistiskās patvalıs izaicinājumam. Modernā laikmeta vērtību relativizācija ir par iemeslu visiem l̦aunumiem, kas iznīcina sabiedrību. (Nespēja mīlēt, vientulība, vardarbība, aborti, noziedzība, pornogrāfija, prostitūcija, AIDS un daudzi citi ļaunumi.) Pret šīm postošajām garīgajām un sociālajām tendencēm ir enerğiski jācīnās, pamatojoties uz vienīgo, mūžīgo un uzticamo Dieva patiesību. ${ }^{28}$

Kopsavelkot līdz šim pateikto, varam secināt, ka protestantu fundamentālisms 21. gadsimta kontekstā būtu raksturojams ar trim galvenajām pazīmēm. Vispirms tā ir principiāla atteikšanās no Bībeles vēsturiski kritiskās pētniecības metodes, tās vietā priekšroku dodot Bībeles interpretācijai, kas tekstu aplūko kā verbāli inspirētu, nemaldīgu un neklūūīgu. Burtiskais lasījums var nest sev līdzi ticību vienīgai pareizai mācībai, izteikti duālistisku pasaules redzējumu un radikāli ekskluzīvas izredzētības apziņu. Jautājumos par Bībeles patiesību izcīnot principiāli svarīgas cīṇas, fundamentālistu argumenti kḷūst radikāli un neiecietīgi, tāpēc nākamā pazīme ir, ka Bībeles burtiskā lasījuma

\footnotetext{
26 Oeming, Hermeneutik, 151-152.

27 Fraser, Atheism, 161-162.

28 Oeming, Hermeneutik, 151.
} 
aizstāvēšanas vārdā tiek attaisnota neiecietība. Tā var būt vērsta gan pret indivīdiem vai grupām ārpus kopienas, bet tikpat daudz pret indivīdiem kopienas iekšienē. Un trešā pazīme ir, ka cīnas lauks ne vienmēr tiek attiecināts tikai uz baznīcas dzīvi skarošiem jautājumiem, bet paplašināts uz visu sabiedrību kopumā. Proti, kad sociālpolitiskās tendences nesaskan ar "Bībeles patiesību", fundamentālisti kḹst skaļi un politiski aktīvi.

\section{Fundamentālisms Latvijas kontekstā}

Ja minētās pazīmes sākam meklēt Latvijas kristīgās ticības telpā, jāatzīst, ka dominējošais aktīiās kristietības profils ir visnotal fundamentālistisks.

Jautājums par sieviešu ordināciju lielāko protestantisko konfesiju vidū joprojām tiek atlikts, un kā arguments tiek arī minēta 2000 gadu senā kristīgās baznīcas tradīcija, kas nekad agrāk nav ordinējusi sievietes. Tomēr pamatojums tam joprojām tiek saskatīts Pāvila norādījumos par sieviešu iesaisti draudzes dievkalpojumos (1.Kor 14:34-35), kas liecina, ka sieviešu ordinācija ir pretrunā Svētajiem Rakstiem. Latvijas Evaņgeêliski luteriskās baznīcas (LELB) arhibīskaps Jānis Vanags, skaidrojot baznīcas pozīciju pēc 2016. gada sinodes balsojuma pret sieviešu ordināciju, ir norādījis, ka jebkuras baznīcas nostāja attiecībā uz sieviešu ordināciju liecina par to, kādu Bībeles skaidrošanas metodi tā ir pieñēmusi. Viņš piemin divas metodes: vēsturiski kritisko Bībeles metodi ar tās galveno atslēgu, kas ņem vērā tekstu pierakstišanas kontekstu un vēsturiskos apstākḷus, un bibliski konservatīvo pieeju, kas vairāk rēḳinās ar kanonisko Bībeli kā Dieva Gara iedvesmotu tekstu..$^{29}$ LELB sinode ar savu balsojumu pret ordināciju par pareizāko izvēlējusies otro. Līdzīgā pozīcijā joprojām atrodas vēl divas protestantiskās baznīcas Latvijā - baptisti un adventisti, kurās laiku pa laikam uzvirmo jautājums par sieviešu ordināciju, taču izvēlētā Bībeles skaidrošanas metode nepiel̦auj jautājuma atrisināšanu pozitīvā veidā. Par to liecina autora (G̦. Roznera) intervijas ar lielāko protestantisko konfesiju garīdzniekiem 2019. un 2020. gadā. Viens no luterāņu mācītājiem argumentēja, ka "mums šodien nekādas izmainas Bībeles interpretācijā nav nepieciešamas. Salamans saka, ka nav nekā jauna šajā pasaulē, cilvēki grēko to pašu desmit baušlu ietvaros, mainījies ir tikai veids, kā tas tiek darīts, bet būtība paliek tā pati. Cilvēce neattīstās, bet degradējas. Apustuḷi bija daudz izglītotāki, spriest spējīgāki un erudītāki nekā šodienas cilvēki. Tāpēc tie, kuri kanonizēja Bībeli, vislabāk arī to saprata un pazina. Mums šodien pilnībā pietiek ar to atklāsmi un skaidrojumiem, kādi jau ir, un mums vairāk ir jāveltī spēki tā nosargāšanai. Svētie Raksti neatbalsta sieviešu ordināciju, un arī fakts, ka divpadsmit apustuḷi bija vīrieši. Un ne tikai tas, jo jautājumu nav iespējams izskatīt ārpus

29 "Jānis Vanags par sievietes lomu un uzdevumiem baznīcā", https://www.apollo.lv/5961022/ janis-vanags-par-sievietes-lomu-un-uzdevumiem-baznica (skatīts 07.09.2020.) 
baznīcas. Ja baznīcai vēsturiski arī vēlāk nekad nav bijušas sievietes kā draudzes vadītājas (mācītājas), un arī šobrīd katoḷu baznīcā un pareizticīgo baznīcā nav, tad ar to arī pilnībā pietiek, lai šodien neko nemainītu. Dzimumu līdztiesības jautājums vēsturiski ir attīstījies, l̦aujot sievietēm piedalīties vēlēšanās, darīt lietas, ko agrāk nevarēja, un tas ir labi, tomēr Svētie Raksti ir nofiksējuši robežu, kuru pārkāpt arī šodien nav vajadzīgs, sievietei nav jābūt mācītājai, un tā ir Dieva griba." ${ }^{30}$

Līdzīgs viedoklis ir arī kādam baptistu mācītājam, kurš uzskata, ka Pāvila norādījumi 1.Kor 14:33 ir tieša Dieva gribas nodošana un tāpēc "šajā gadījumā nepaklausība Pāvilam, būtu arī nepaklausība Dieva gribai. Var jau nepaklausīt, bet tad ir jārēḳinās ar sekām - tiks izjaukta Dieva ieliktā kārtība jeb attiecīgās ētikas protonormas, kas sabojās draudzi un dos vietu grēkam un iespēju velnam ietekmēt draudzi." ${ }^{\prime 1}$ Protams, šajā jautājumā viedokl̦i ne vienmēr ir tik kategoriski. Vairāki aptaujātie atzīst, ka ir bijuši liecinieki l̦oti svētīgai un draudzei palīdzošai sieviešu sludināšanai un tāpēc nenoliedz, ka sievietēm varētu būt īpašs aicinājums no Dieva, tomēr Pāvila norādījumu neviens neuzdrošinājās nosaukt par mūsdienās aktualitāti zaudējušu. Tāpēc tiek piedāvāts savā ziṇā formāls risinājums, kas, no vienas puses, neliedz sievietei mācīt un sprediķot, bet, no otras puses, paliek saskaņā ar visas Bībeles kā pārlaicīga vēstijuma no Dieva idejas un neparedz ordināciju kā apstiprinājumu sieviešu kalpošanai. "Es teiktu, sieviete var sludināt, bet ne dominēt. Viñas pašas labā, viña sludinot var atrasties zem vīra vai mācītāja autoritātes, kurš viņu apstiprina un iedrošina." ${ }^{32}$

Interesanti, ka arī intervētais septītās dienas adventistu garīdznieks pieturas pie šādas izpratnes, tomēr nenoliedz, ka šajā jautājumā viedoklis augstākajā draudzes līmenī (Ģenerālkonferencē, kas apvieno visas adventistu draudzes pasaulē) varētu mainīties. "Uzticama un droša Bībeles skaidrošana ir baznīcas (organizācijas) ietvaros, caur ko darbojas Dievs. Organizācija nozīmē teologu komisijas, kas izskata visādas jaunas idejas un pieņem lēmumu, vai tās ir vērā ņemamas." Tāpēc šis garīdznieks nav tik kategorisks sieviešu ordinācijas jautājumā, bet paļaujas uz organizāciju, ko vada Dieva gars. Ja tajā ar vairākumu tiks nobalsots par to, ka sievietes ir jāordinē, viņš to labprāt pieñems. $^{33}$

Intervijas atspoguḷ l̦ loti plašu izpratni par Bībeles inspirācijas procesu. Neviens no 11 intervētajiem nepiekrita klasiskajiem luteriskās ortodoksijas dogmatiķu apgalvojumiem par verbālo inspirāciju, bet kā svarīgu faktoru tekstu pierakstā norādīja uz autoru cilvēcisko ierobežotību. Tāpat arī neviens nepiekrita, ka ticība Bībeles inspirācijai

\footnotetext{
30 Intervija Nr. 1 autora arhīvā, 11.09.2019.

31 Intervija Nr. 2 autora arhīvā, 31.01.2020.

32 Intervija Nr. 3 autora arhīvā, 27.01.2020.

33 Intervija Nr. 4 autora arhīvā, 12.09.2019.
} 
nozīmē, ka ir iespējama tikai viena vienīga pareizā interpretācija. Kā svarīgi, vērā ņemami faktori, interpretējot tekstu, tika minēta nepieciešamība rēķināties ar žanru, sarakstǐšanas laiku, vēsturisko kontekstu un kultūrvidi. Tajā pašā laikā jautājumā par sieviešu ordināciju pozitīvi un atbalstoši izteicās tikai četri no 11 intervētajiem. Interesanti, ka, nepiekrītot verbālās inspirācijas idejai, tajā pašā laikā pieci intervētie izteica pilnīgu piekrišanu luteriskās ortodoksijas idejai par Svētajiem Rakstiem kā brīviem no kḷūuām un maldiem un pāri stāvošiem cilvēka kritikai, kas ir viens no fundamentālisma stūrakmeñiem. Intervijas parāda, ka atbildes uz aktuāliem jautājumiem bieži vien tiek meklētas ārpus Bībeles tekstiem, argumentējot pie reālās situācijas, veselā saprāta un pat zinātnes, taču visu interpretāciju galarezultāts liecina par bažām par morāles kritumu sabiedrībā un kristīgo vērtību degradēšanos, kas varētu notikt baznīcā. Tās varētu nosaukt arī par bailēm no pārmaiņām sabiedrībā, kas varētu izraisīt nevēlamas pārmaiņas baznīcā. Kā parāda intervijas ar dažādiem Latvijas garīdzniekiem, fundamentālistiskai Rakstu interpretācijai mūsu zemē ir ļoti spēcīgas pozīcijas. Tas, protams, nenozīmē, ka katrā konkrētā gadijjumā uzreiz varam runāt par fundamentālismu, jo, kā jau noskaidrojām, fundamentālisms ir saistīts ne tikai ar noteiktu Bībeles eksegēēi un interpretāciju.

Kā liecina Latvijas Universitātes profesora Valda Tēraudkalna pētijums par religiskajām tendencēm pēc Latvijas neatkarības atjaunošanas, kristietība postsekulārisma laikmetā arī mūsu zemē piedzīvo fragmentēšanos. Tās pamatā ir dažādas konfesionālas nesaskaņas un domstarpības gan jau pieminētajā jautājumā par sieviešu ordināciju, gan mēginājumos konfesionālo ticību kontekstualizēt un pielāgot savam laikmetam, gan arī jautājumos par LGBT tiesībām. ${ }^{34}$ Šĩ fragmentācija ir sāpīgs process, kura neatņemama sastāvdaļa ir kontraverses teologiskajos jautājumos, kas nereti beidzas ar citādi domājošo un savu ticību praktizējošo izstumšanu. V. Tēraudkalns savā pētijjumā piemin gan sabiedriskajos medijos izskanējušo adventistu mācītāja Ivo Roderta atlaišanu 2016. gadā, gan luterāñu mācītāja Jura Rubeņa labprātīgo atteikšanos no mācītāja kalpošanas 2018. gadā. ${ }^{35}$ Pēc autoru domām, abi šie gadījumi ir raksturojami kā tipiska kristīgā fundamentālisma neiecietība pret citādi domājošajiem. Abos gadījumos garīdznieki tika apsūdzēti novirzē no konfesionālās mācības. Adventistu Rīgas 1. draudzes 2016. gada 18. janvāra vēstulē adventistu Latvijas draudžu savienībai teikts: "Esam ienākuši adventistu draudzē, uzticoties Dieva Vārdā pamatotajai mācībai, un vēlamies palikt šajā skaidrajā mācībā, nevis sekot mācītāja I. Roderta "progresīvo un cilvēcisko ideju labirintos", ko šobrīd dzirdam Sabata dievkalpojumos." ${ }^{36}$

34 Skatīt Valdis Tēraudkalns, "Religion in Latvia after the Fall of the Soviet System: Fragmentation and Postsecularism", in Occasional Papers on Religion in Eastern Europe Vol. 40: Iss. 6, Article 2 (2020): 1-20.

35 Tēraudkalns, Religion.., 5, 7.

36 Vēstule autora arhīvā. 
Situāciju ar luterāṇu mācītāja Jura Rubeņa aiziešanu aprakstījis Rīgas Lutera draudzes mācītājs Linards Rozentāls: "Sākot no 2017. gada bēdīgi slavenā Klusās nedēḷas konventa 11. aprïlī šajā un turpmākajos konventos Juris Rubenis aizskarošā un cilvēka cieņu nievājošā veidā vairākkārt tika apsūdzēts par savām un citu autoru paustajām domām un uzskatiem un pat par pasaulē pazīstamiem mākslas darbiem, kas atrodami grāmatās "levads kristīgajā meditācijā" un "Viņa un viņš". Tikai 20. jūnijā uz konventu pirmo reizi tika uzaicināts pats Juris Rubenis. Šajā konventā Juris Rubenis prāvestam un arī konventā klāt esošajam arhibīskapam iesniedza vēstuli ar lūgumu, lai Rīgas prāvesta iecirkna konvents paskaidro, vai tas atrodas kontinuitātē ar LELB teologisisko tradīciju, kura šo baznīcu ir veidojusi un kura ir palīdzējusi tai pastāvēt padomju laikā, un kura vienmēr bijusi konstanta šīs baznīcas daḷa - plašas un daudzveidīgas teologiskās domas tradīcija, kas rada gaisotni, kura palīdz katram cilvēkam garīgi nobriest un atrast savu celıu. Uz šo retorisko jautājumu konvents 2018. gada 23. janvārī apstiprināja atbildi Jurim Rubenim, ka šāda tradīcija "mūsu baznīcā nav paredzēta"."’37 Protams, aplūkotie piemēri nav vienīgie un tiek pieminēti izraisītās sabiedriskās rezonanses dēl, taču tie uzskatāmi demonstrē kristīgajam fundamentālismam raksturīgo principialitāti, kas nevēlas savā vidū tolerēt citādi domājošos, velk ciešas robežlīnijas un pieprasa garīdznieku un laju pilnīgu saskaņu ar "Dieva Vārda skaidro mācību". Fundamentālismu raksturojošais separātisms un vēlme pēc morālas un doktrināras tīrības neizbēgami noved pie radikāliem iekšējās attīrī̌sanās procesiem. ${ }^{38}$ Bībeles burtiskā lasījuma aizstāvēšanas vārdā tiek attaisnota neiecietība, ko Rozentāls l̦oti precīzi raksturo: "Nezināšana un nevēlēšanās zināt, neizpratne un nevēlēšanās saprast, ieklausīties, sadzirdēt. Nevēlēšanās cienīt un mīlēt." ${ }^{\prime \prime}$

Divas pirmās fundamentālisma pazīmes - Bībeles nemaldīgums un nekḷ̂ūīgums un neiecietība - mūsu aplūkotajos piemēros ir vairāk vērstas uz baznīcas iekšējo dzīvi, bet trešā pazīme mūs iepazīstina ar fundamentālismu tā kontraversē ar moderno sabiedriski politiskajā līmenī. Ja atgriežamies pie jau minētās Marsdena definīcijas, ka "fundamentālists ir evaņgelikālis, kurš ir dusmīgs", Latvijā līdz šim esam bijuši liecinieki pietiekami skaļiem kristīgo kopienu mēǵinājumiem aktīvi iesaistīties politiskajās norisēs un ietekmēt valdības lēmumus. Uz brīdi palūkosimies uz šo jautājumu mazliet plašāk. Viena no valstīm, kurā ir pietiekami senas un dziļas kristiešu iesaistī̌̌anās

37 Par Juri Rubeni un kaislībām baznīcā. Māc. Linards Rozentāls. https://www.sieviesuordinacija.lv/, pārpublicēts no Linarda Rozentāla 2018. g. 14. februāra ieraksta vietnē Facebook (skatīts 07.09.2020.)

38 Fraser, Atheism, 188.

39 Par Juri Rubeni un kaislībām baznīcā. Māc. Linards Rozentāls. https://www.sieviesuordinacija. Iv/, pārpublicēts no Linarda Rozentāla 2018. g. 14. februāra ieraksta vietnē Facebook (skatīts 07.09.2020.) 
politiskajās norisēs tradīcijas, ir ASV. Baznīcām apvienojoties ar politiskajiem spēkiem, vēsturiski tiek veidotas dažāda veida kristīgās alianses. Piemēram, konservatīvie evañgelikāli ir apvienojušies ar labējiem republikāņu spēkiem, bet progresīvie evaņgélikāļi ar kreisajiem demokrātu spēkiem. Šīm aliansēm ir bijusi būtiska nozīme gan Amerikas prezidentu vēlēšanās, gan arī dažādās sociālā taisnīguma un izglìtības kampaṇās. ${ }^{40}$ Pēc neatkarības atjaunošanas arī Latvijā pēc citu evanggeelisko alianšu parauga izveidojās Latvijas Evangéêliskā alianse (LEA), kurā ir apvienojušās vairākas baptistu, Vasarsvētku un metodistu draudzes, bet starp tās atbalstītājiem ir teju visas tradicionālās Latvijas konfesijas. LEA ir saistīta ar Eiropas Evangêēlisko aliansi (EEA) un Pasaules evaņgêelisko aliansi (PEA), kḷūstot par tās biedru, automātiski kḹūst arī par EEA un PEA biedru. Tā ir viena no tiešākajām Latvijas kristīgo kopienu sasaistēm ar evanggelikālo kustību pasaulē, un mēǵinājumu ietekmēt politisko situāciju Latvijā var saskatīt arī LEA darbībā (vismaz tās sākuma stadijā, jo pašlaik alianses darbībā, šḳiet, iestājies atslābuma periods). Biedrība LEA dibināta 2006. gadā. Viens no alianses goda biedriem ir pirmais atjaunotās brīvvalsts prezidents Guntis Ulmanis, bet viena no redzamākajām aktivitātēm bija, piemēram, Latvijas valsts Lūgšanu brokastis 2010. gadā, kurās piedalījās arī toreizējais Valsts prezidents Valdis Zatlers. Tomēr jāatzīst, ka atšķirībā no Amerikas Latvijas evañgéliskās alianses loma politiskajos procesos nav tik jūtama. Tiesa, jāatzīst, ka atšḳirībā no Amerikas situācijas Latvijas Lūgšanu brokastu reālā ietekme uz politiskajiem un ekonomiskajiem procesiem valstī nav pietiekami pētīta.

Droši vien Latvijas situācijā mēs nevaram runāt par evaņgélikālismu tādā izpratnē, kā tas ir ASV. Ja tomēr šādu apzīmējumu lietojam, evanggelikālisms Latvijā nav monolīts, bet sadrumstalots un pretrunīgs. LEA valdē darbojas dažādu konfesiju pārstāvji, un, iespējams, savstarpēji novilktās stingrās robežlīnijas un atšķirīgie redzējumi nel̦auj pilnībā îstenoties organizācijas vīzijai. Tāpēc par sava veida alternatīvu kḷıuva neatkarīgās draudzes "Kristus pasaulei" organizētās ekumeniskās sapulces Skonto hallē ar nosaukumu "Lūgšana par Latviju”. Zīmīgi, ka 2019. gadā līdzās mērķim organizēt vēl vienu uz ekumenismu orientētu plašu evaņgelizācijas pasākumu galvenā lūgšanu sapulces iniciatīva bija parakstītas petīcijas un atklātas vēstules par kristīgām un ǵimenes vērtībām Latvijā iesniegšana Latvijas Republikas Saeimas deputātiem un Saeimā pārstāvētajām politisko partiju frakcijām. Atklātā vēstule tika iesniegta arī Valsts prezidentam un Ministru kabinetam, kā arī nosūtīta visām pilsētu un novadu pašvaldībām. Vēstulē tika uzsvērts, kādas negatīvas sekas Latvijai rada kristīgo morāles standartu ignorēěana izglìīibas sistēmā, kā arī bezatbildīga dzìvesveida un viendzimuma attiecību popularizēšana. Latvijas vadītāji tika aicināti atbalstīt idejas, iniciatīvas, likumdošanas projektus

40 Charles J. Scalise, "Protestant Evangelicalism" in The Wiley-Blackwell Companion to Practical Theology, ed. Bonnie J. Miller-Mc Lemore (Blackwell Publishing Limited, 2012), 582. 
un noteikumus, kuri atbilst valsts konstitūcijā noteiktajām vērtībām, kā arī aizsargāt tradicionālo g̊imenes modeli kā Satversmē garantētu nemaināmu vērtību. ${ }^{41}$

Viendzimuma pāru attiecību legalizēšanas jautājums ir bijis viens no galvenajiem kopīgajai cīnaai vienojošiem faktoriem to kristīgo spēku vidū, kas pēc saviem ieskatiem iestājas pret morāles piesārņojumu. Tāpat varam atcerēties 2018. gada karstās diskusijas par "Eiropas Padomes Konvencijas par vardarbības pret sievietēm un vardarbïbu gimenē novēršanu un apkarošanu" ratificēšanas jautājumu. Četru tradicionālo konfesiju līderi parakstijja atklātu vēstuli, aicinot Saeimas deputātus labot tajā esošās nepilnības. Lai arī konvencijas mērḳis ir vardarbības pret sievietēm novēršana, atklātās vēstules autoru satraukums bija vērsts pret to, ka "konvencija neaicina cīnīties ar patiesajiem vardarbības cēloṇiem, bet paver iespējas uzspiest Latvijā sociālā dzimuma (gender) ideolog̣ijā balstītu sabiedrības pārveidošanas projektu"42. N̦emot vērā šo kristīgo konfesiju ierosināto sabiedrïbas spiedienu, Stambulas konvencijas ratificēšana tika atlikta uz nenoteiktu laiku. 2019. gada oktobrī notika Tautas lūgšanu sapulce "Dievs, svētī Latviju!", kurā tika sagatavota Pateicības vēstule Latvijas valsts vadītājiem. To parakstijja visi Latvijas lielāko kristīgo konfesiju vadītāji, un tās teksts parāda galvenos "karstos punktus", kur cita starpā minēta Stambulas konvencijas neratificēšana un Dzīvesbiedru likumprojekta izskatīšanas noraidīšana. ${ }^{43}$ Kā redzams, pārliecība par to, ka ir jācīnās par Bībeles patiesību, rada pietiekami aktīvu un skaļu politisko darbību, kas nes līdzi arī asas debates un fragmentāciju dažādās kopienās. Par to liecina kaut vai 33 Latvijas zinātnieku parakstìtā atklātā vēstule ar aicinājumu ratificēt Stambulas konvenciju ${ }^{44}$ un 52 dažādu baznīcu pārstāvju tādas pašas atklātas vēstules parakstī̌sana ${ }^{45}$. Tomēr, neskatoties uz to, kristīgo fundamentālistu ierosinātās politiskās iniciatīvas Latvijā ir pietiekami efektīgas. Mēs varam novērot l̦oti ievērojamu sabiedrības un arī kristīgo konfesiju atbalstu fundamentālismam kā Latvijas kristīgo telpu būtiski raksturojošam fenomenam.

41 Pateicības vēstule Latvijas valsts vadītājiem, https://parlatviju.lv/peticija/pateicibas-vestulelatvijas-valsts-vaditajiem (skatīts 08.09.2020.)

42 Latvijas kristīgo baznīcu vadītāju atklāta vēstule par Stambulas konvenciju, http://katolis.lv/ 2016/05/latvijas-kristigo-baznicu-vaditaju-atklata-vestule-par-stambulas-konvenciju/ (skatīts 07.09.2020.)

43 Pateicības vēstule Latvijas valsts vadītājiem, https://parlatviju.Iv/peticija/pateicibas-vestule-latvijas-valsts-vaditajiem (skatīts 08.09.2020.)

4433 Latvijas zinātnieki atklātā vēstulē aicina ratificēt Stambulas konvenciju, https://satori.lv/ article/33-latvijas-zinatnieki-atklata-vestule-aicina-ratificet-stambulas-konvenciju (skatīts 08.09.2020.)

45 https://satori.lv/article/baznicas-parstavji-atklata-vestule-pauz-atbalstu-stambulas-konvencijai (skatīts 08.09.2020.) 

uzskatīts par fenomenu, kam tajā vairs nav vietas, tomēr tas tā nav, jo fundamentālisms ir mūsdienu cilvēka vajadzība. Fundamentālisms veidojas dialektikā starp vienas sabiedrības dal̦as vajadzību pret izmaiñām un otras sabiedrības daļas reakciju uz tām kā nevēlamām un bīstamām. Mūsdienu cilvēka vajadzība ir stabilitāte un drošība arī kristīgās ticības jautājumos. Daļa cilvēku to atrod, turoties pie inspirēta Bībeles teksta, kas ir nemaldīgs un nekḷūdīgs. Tomēr brīdī, kad šì pārliecība tiek aizstāvēta vai tās ietvaros tiek reagēèts uz kādām sabiedrības tendencēm, fundamentālisms var kḹut skalšs, neiecietīgs un aizskarošs.

Fundamentālisma eksegeēze ir orientēta uz vienas patiesības uzturēšanu. Arī tekstu interpretācijai būtu jābūt vienai tomēr praktiski kristīgo interpretāciju dažādība liecina par pluralitāti. Tāpēc, lai pieturētos un aizstāvētu savu eksegétisko skatījumu, fundamentālismam nepieciešami dažādi palīglīdzekḷ, viens no kuriem ir baznīcas autoritāte un tās novilktās stingrās robežas, kuras nedrīkst pārkāpt. ${ }^{46}$ Baznīca uzñemas disciplinētāja lomu, kas citādi domājošos izstumj. Aizsedzoties ar "nemainīgo patiesību" un "Rakstu autoritāti", kristīgo fundamentālistu teoloǵija patiesībā apspiež bezgalīgo daudzveidību, ko atklāj Raksti un Trīsvienības ieklaujošā teoloǵija. ${ }^{47}$

Latvijas kristīgajā sabiedrībā un arī garīdzniecībā ir vērojamas fundamentālisma iezīmes - izteikta pārliecība par Bībeles nemaldīgumu un nekḹūī̄gumu, bažas, ka laikmeta pārmaiņu dēl tiek zaudēta Bībeles autoritāte un uzspiesta tikumu degradācija. Fundamentālismam aizstāvot savas pozīcijas, šie jautājumi tiek aktualizēti sociālpolitiskajā līmenī un attiecīgās paradigmas tiek mēgināts uzspiest visai sabiedrībai.

\section{SUMMARY}

\section{Fundamentalism as a phenomenon of Christian faith in Latvia}

Although in the modern age fundamentalism is sometimes considered a phenomenon that no longer has a place in it, it is not so. Fundamentalism is formed in the dialectic between the need of one part of society for change and the reaction of another part of society to it as undesirable and dangerous.

The study examines the history of the formation of Christian fundamentalism, focussing on three characteristic features of the phenomenon in the context of the $21^{\text {st }}$ century. Firstly, it is a fundamental abandonment of the historically critical method of researching the Bible, preferring instead a literal interpretation of the Bible that views the text as verbally inspired,

46 Fraser, Atheism, 222-223.

47 Chul Min Jun, "The paradigm shift of practical theology and theological practice to overcome modernism and postmodernism" in Pacific Science Review, Volume 16, Issue 2, (2014): 156-166. 
inerrant, and infallible. Literal reading can concur with a belief in the only correct doctrine, a distinctly dualistic vision of the world, and a sense of radically exclusive self-awareness. When it comes to winning fundamental battles over biblical truth, fundamentalist arguments become radical and intolerant. Thus, the next feature is justification of intolerance in the name of defending the literal reading of the Bible. It can be directed against individuals or groups outside the community, but equally against individuals within the community. The third feature is that the battlefield is not always limited to matters affecting the life of the church but extends to society as a whole. Namely, when socio-political tendencies are not in line with the "biblical truth", fundamentalists become loud and politically active.

Authors argue that there are clear signs of fundamentalistic tendencies in Latvian Christian society and clergy. Interviews with clergy show a strong belief in the inerrancy and infallibility of the Bible. The exegesis of fundamentalism is oriented towards the maintenance of a single truth. There should be a single interpretation of the texts, therefore, in order to adhere to and defend its exegetical view, fundamentalism needs various aids, including the authority of the church and the strict boundaries, which must not be violated. The study looks at two examples, where certain Latvian denominations have taken on the role of disciplinarians, pushing out dissidents. The political activities of the Christian denominations in Latvia also reveal fears that the modern age may bring about the loss of Bible's authority. Consequently, morality is enforced, and Fundamentalism defends its positions trying to impose the relevant paradigms upon the entire society. 